\title{
Luminescent 2,7-Disubstituted Germafluorenes
}

\author{
Douglas W. Hammerstroem, Janet Braddock-Wilking*, and Nigam P. Rath
}

\begin{abstract}
A series of six luminescent 2,7-alkynyl(aryl)-3,6-dimethoxy-9,9-diphenylgermafluorenes were synthesized from the corresponding 2,7-dibromo-3,6-dimethoxy-9,9-diphenylgermafluorene utilizing a palladium-catalyzed Sonogashira cross-coupling reaction to incorporate different alkynyl(aryl) groups at the 2,7-positions of the germafluorene ring. The new germafluorenes show an intense absorption band centered between 371-388 $\mathrm{nm}$ and moderate to strong emission in solution between $401-443 \mathrm{~nm}\left(\Phi_{\mathrm{F}}=\right.$ 0.65-0.83) as well as emission from the solid-state. Germafluorenes $\mathbf{4 a - 4 f}$ were characterized by multinuclear ${ }^{1} \mathrm{H}$ and ${ }^{13} \mathrm{C}\left\{{ }^{1} \mathrm{H}\right\}$ NMR, EA, DSC, TGA, UV-Vis, and fluorescence spectroscopy. TGA and DSC studies of germafluorenes $\mathbf{4 a - 4 f}$ showed high thermal stability. The molecular structures of four of the germafluorenes, $\mathbf{4 c - 4 f}$ were determined by X-ray crystallography.
\end{abstract}

\section{Introduction}

Over the last decade, Group 14 containing conjugated $\pi$-electron systems such as siloles, dithienosiloles, and silafluorenes have received significant attention due to their unique optoelectronic properties and potential applications as components in organic light emitting diodes (OLEDs), photovoltaic devices, field-effect transistors (FETs), and as chemical sensors for nitroaromatic. [1-25] The optoelectronic properties observed in these systems have been attributed to $\sigma^{*}-\pi^{*}$ conjugation between the exocyclic groups at the Group 14 center and the butadiene unit of the ring giving rise to a low energy LUMO level.[22] Further tuning of the optoelectronic properties can be achieved by the incorporation of substituents on the ring structure.[4, 10-11, 27-30] While silafluorene molecules and polymers have been investigated for these applications, germafluorene monomers and polymers have been relatively unexplored. Recently, Leclerc and coworkers prepared a series of air stable germafluorene homopolymers and alternating copolymers for FETs and photovoltaic cell applications.[31] Wei and coworkers have investigated a germafluorene-fluorene copolymer that exhibited efficient blue emission from a single layer EL device.[32] Tilley and coworkers reported the synthesis of a series of fluorinated 
heterofluorenes including germafluorene systems that exhibited high electron affinities and showed great potential as electron transporting materials.[33-35] A series of spirocyclic germafluorene-germoles that exhibited good photo- and thermal stability and with tunable luminescence were reported recently by Rivard and coworkers. [36] Many of the germafluorenes reported to date have been prepared by a lithium- halogen exchange reaction between a dihalobiphenyl precursor and $n \mathrm{BuLi}$, followed by reaction with an appropriate dichlorogermane. [31, 34-37] Recent reports have shown that transition-metal catalyzed routes can be used for the formation of germafluorene and silafluorene derivatives. [29, 38-40] An inexpensive, simplified, and higher yielding route to the tetra-halogenated precursor, 4,4'-dibromo2,2'-diiodo-5,5'-dimethoxy-1,1'-biphenyl was reported by Huang et. al., [41] and improved by Ozin et. al.

[42] We recently reported an improved method based on these previous reports for the synthesis of 2,7dibromo-3,6-dimethoxy-9,9-diphenylsilafluorene starting from 4,4'-dibromo-2,2'-diiodo-5,5'-dimethoxy1,1'-biphenyl giving higher yield and shorter reaction time. [44] Herein, we report the synthesis and characterization of a series of related germafluorenes using the improved synthetic method to obtain the precursor 2,7-dibromo-3,6-dimethoxy-9,9-diphenylgermafluorene.

\section{Results and Discussion}

2.1. Synthesis and characterization.

Previous reports have shown that the preparation of 4,4'-dibromo-3,3'-dimethoxy-1,1'-biphenyl 1 can be achieved by reaction of $o$-dianisidine through bromination, followed by an iodination reaction which utilizes the para-directing methoxy substituents to form 4,4'-dibromo-2,2'-diiodo-5,5'-dimethoxy-1,1'biphenyl 2. [41, 42] The precursor, 2,7-dibromo-3,6-dimethoxy-9,9-diphenylgermafluorene 3 can be obtained via a lithium-halogen exchange of 2 which selectively forms a 2,2'-dilithio-4,4'-dibromo-5,5'dimethoxybiphenyl intermediate. However, existing routes were low yielding (12\%) or were difficult to reproduce consistently and required long experimental times. [41-43] A new reaction method was recently developed for the ring closure step for the synthesis of 2,7-dibromo-3,6-dimethoxy-9,9diphenylsilafluorene analogous to germafluorene 3. [44] With an improved method and overall high- 
yielding, inexpensive, and simple pathway in hand to synthesize $\mathbf{3}$, the final step is the synthesis of a group of novel 2,7-disubstituted germafluorenes $\mathbf{4 a - 4 f}$, which consists of the reaction of compound $\mathbf{3}$ in a palladium-catalyzed cross-coupling reaction utilizing Sonagashira conditions with (aryl)alkynes linkages containing different terminal aryl groups. This synthetic route is outlined in Scheme 1.
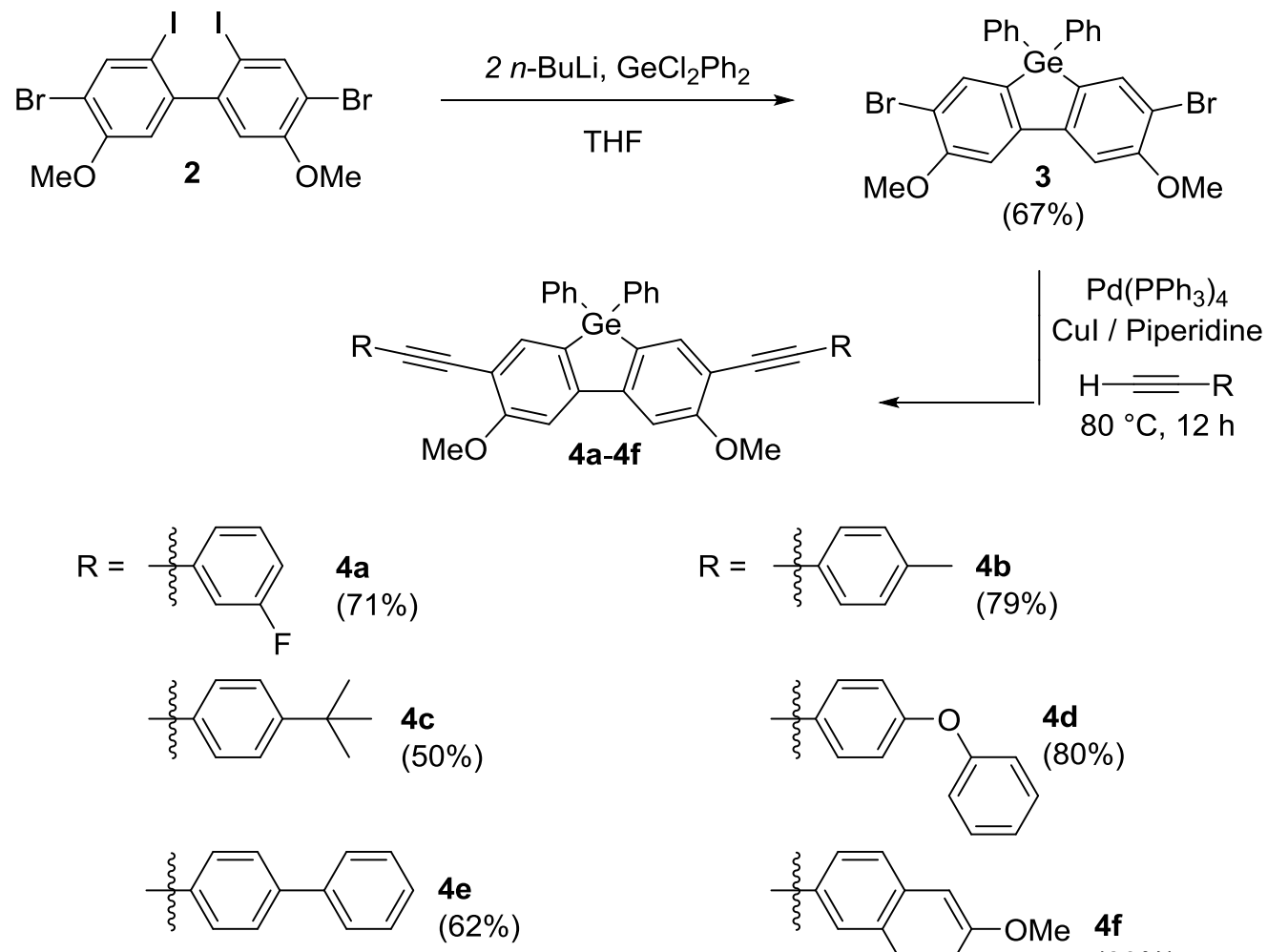

$(79 \%)$

$62 \%)$

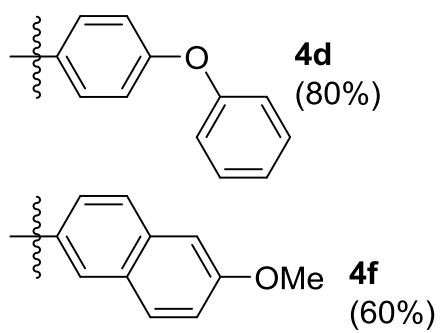

Scheme 1. Synthesis of germfluorenes $\mathbf{4 a - 4 f}$

Using similar reaction conditions as used for the preparation of the analogous 2,7-dibromo-3,6dimethoxy-9,9-diphenylsilafluorene, the reaction of $\mathbf{2}$ with $n \mathrm{BuLi}$ at low temperature followed by the addition of $\mathrm{Ph}_{2} \mathrm{GeCl}_{2}$ afforded the corresponding 2,7-dibromo-3,6-dimethoxy-9,9-diphenylgermafluorene 3 in $67 \%$ yield as a white solid. Palladium-catalyzed Sonagashira cross-coupling reactions [41-45] were used to couple a series of alkynyl(aryl) groups to the 2,7-sites of germafluorene 3 to produce the 2,7alkyny(aryl)-3,6-dimethoxy-9,9-diphenylgermafluorenes 4a-4f, as shown in Scheme 1. Compound 3 was found to be weakly fluorescent in both the solution and solid states but during the cross-coupling reaction a more intense fluorescence in solution was observed after stirring for $30 \mathrm{~min}$ at $80{ }^{\circ} \mathrm{C}$, indicating 
the formation of germafluorenes $\mathbf{4 a - 4 f}$. Germafluorenes $\mathbf{4 a - 4 f}$ were isolated as light yellow crystalline solids in moderate to good yields (50-80\%). Germafluorenes 4a-4f exhibited strong blue emission in both the solution and the solid-state (solution state quantum yields ranged from 0.64-0.83 for $\mathbf{4 a - 4 f}$ ). Like the corresponding silafluorenes, germafluorenes $\mathbf{4 a - 4 f}$ faintly shimmered blue under ambient lighting conditions. Germafluorenes 4a-4f were characterized by ${ }^{1} \mathrm{H}$ and ${ }^{13} \mathrm{C}\left\{{ }^{1} \mathrm{H}\right\}$ NMR, HR-MS (4a-4d), EA, UV-Vis and fluorescence spectroscopy, TGA, DSC, and X-ray crystallography (4c-4f).

The ${ }^{1} \mathrm{H}$ NMR spectroscopic data for germafluorenes $\mathbf{4 a - 4 f}$ showed singlet resonances between 7.85-8.00 ppm and 4.08-4.11 ppm for the isolated proton between the methoxy substituent and the five-membered ring, and for the methoxy protons, respectively. The ${ }^{13} \mathrm{C}\left\{{ }^{1} \mathrm{H}\right\}$ NMR data showed the resonance for the ring carbons bearing the methoxy substituents at $162 \mathrm{ppm}$ and the resonance for the methoxy carbon at 56 ppm. The resonances for the alkynyl carbons ranged between 93-95 and 85-87 ppm. The $\beta$-carbon of the central five-membered ring was observed at 148 ppm for germafluorenes $\mathbf{4 a - 4 f}$. These resonances were comparable to previously reported values on the analogous silafluorenes we recently reported and other related silafluorenes system. [42-45]

\subsection{X-ray crystal structures}

Crystals of germafluorenes $\mathbf{4 c - 4 f}$ were obtained by slow evaporation from $\mathrm{CH}_{2} \mathrm{Cl}_{2}$ solution and the molecular structures were determined by X-ray crystallography (see Experimental Section).

Crystallographic and data collection parameters for $\mathbf{4 c - 4 f}$ are summarized in Table 1. The molecular structures of $\mathbf{4 c - 4 f}$ along with selected bond distances and angles are shown in Figures 1-4, respectively. Compound $\mathbf{4 d}$ crystallized with 0.5 molecule of methylene chloride per unit cell. Compounds $\mathbf{4 c - 4 f}$ exhibit varying degrees of twisting of the alkynyl(aryl) groups at the 2,7-positions of the germafluorene relative to the core. Twisting is also observed with the outer aryl groups relative to the core in $\mathbf{4 d}$ and $\mathbf{4 e}$. The bond distances and angles are similar for the core of the four structures. The endocyclic C-Ge-C angles at the Ge center range from $88.94(11)-89.02(6)^{\circ}$ and are significantly smaller compared to the 
exocyclic C-Ge-C angles which range from 108.76(12)-116.3(4) ${ }^{\circ}$, with the $\mathrm{C}-\mathrm{Ge}-\mathrm{C}$ exocyclic angles being larger for $\mathbf{4 e - 4 f}\left(114.70(6)-116.3(4)^{\circ}\right)$ compared to $\left.\mathbf{4 c - 4 d}(108.91(9)-108.76912)^{\circ}\right)$. The bond angles and distances of the core ring are similar to other germafluorene compounds that have been characterized by X-ray crystallography. [29, 33, 34, 36, 46, 47]

Table 1. Crystallographic and Data Collection Parameters for $\mathbf{4 c - 4 f ^ { a }}$

\begin{tabular}{|l|l|l|l|l|}
\hline & $4 \mathrm{c}$ & $4 \mathrm{~d}$ & $4 \mathrm{e}$ & $4 \mathrm{f}$ \\
\hline Formula & $\mathrm{C}_{50} \mathrm{H}_{46} \mathrm{O}_{2} \mathrm{Ge}$ & $\begin{array}{l}\mathrm{C}_{109} \mathrm{H}_{78} \mathrm{Cl}_{2} \mathrm{Ge}_{2} \\
\mathrm{O}_{8}\end{array}$ & $\mathrm{C}_{54} \mathrm{H}_{38} \mathrm{O}_{2} \mathrm{Ge}$ & $\mathrm{C}_{52} \mathrm{H}_{38} \mathrm{O}_{4} \mathrm{Ge}$ \\
\hline cryst syst & 751.46 & 1731.79 & 791.43 & 799.41 \\
\hline space group & Triclinic & Triclinic & Triclinic & Monoclinic \\
\hline$a, \AA$ & $\mathrm{P} \overline{1}$ & $\mathrm{P} \overline{1}$ & $\mathrm{P} \overline{1}$ & $\mathrm{P} 2{ }_{1} / \mathrm{c}$ \\
\hline$b, \AA$ & $12.7045(7)$ & $12.4753(11)$ & $12.3334(8)$ & $17.1271(19)$ \\
\hline $\mathrm{c}, \AA$ & $17.4941(9)$ & $12.5596(11)$ & $13.1508(9)$ & $21.292(2)$ \\
\hline$\alpha$, deg & $19.8723(10)$ & $14.1904(12)$ & $13.7595(9)$ & $11.1484(13)$ \\
\hline$\beta$, deg & $112.268(3)$ & $104.144(2)$ & $114.807(3)$ & 90 \\
\hline$\gamma$, deg & $91.962(3)$ & $92.740(2)$ & $102.785(3)$ & $107.175(8)$ \\
\hline$V, \AA^{3}$ & $99.094(3)$ & $94.393(3)$ & $90.815(4)$ & 90 \\
\hline $\mathrm{Z}$ & $4014.4(4)$ & $2144.6(3)$ & $1961.0(2)$ & $2111.7(3)$ \\
\hline$d_{\text {calc }}, \mathrm{g} / \mathrm{cm}^{3}$ & 4 & 1 & 2 & 4 \\
\hline$\mu, \mathrm{mm}^{-1}$ & 1.243 & 1.341 & 1.340 & 1.367 \\
\hline $\mathrm{R} 1{ }^{b}{ }^{\mathrm{wRR}}{ }^{c}$ & 0.802 & 0.824 & 0.825 & 0.837 \\
\hline goodness-of-fit on $F^{2}$ & 1.016 & $0.0509,0.1436$ & $0.0365,0.0891$ & $0.0859,0.2066$ \\
\hline
\end{tabular}

${ }^{a} \lambda,=0.71073 \AA(\mathrm{Mo}), T=-100(2) \mathrm{K} .{ }^{b} \mathrm{R} 1=\left(\sum|| F_{\mathrm{o}}|-| F_{\mathrm{c}} \mid\right) / \sum|| F_{\mathrm{o}} \mid \cdot{ }^{c} \mathrm{wR} 2=\left[\left(\sum \mathrm{w}\left(F_{\mathrm{o}}{ }^{2}-F_{\mathrm{c}}{ }^{2}\right)^{2}\right) / \sum \mathrm{w}\left(F_{\mathrm{c}}{ }^{2}\right)^{2}\right]^{1 / 2}$.

All crystals were yellow needles.

Compounds $\mathbf{4 c - 4 f}$ all crystallized in a parallel arrangement in the solid-state with intermolecular aromatic separations between adjacent molecules of ca. $4.0 \AA$ or greater but are offset such that there is minimal intermolecular $\pi$-overlap between the conjugated systems (see Supporting Information). Compound 4d displayed some overlap between the two alkynyl carbons with two of the carbons on the dibenzo-ring at $3.323 \AA$ in adjacent molecules. 


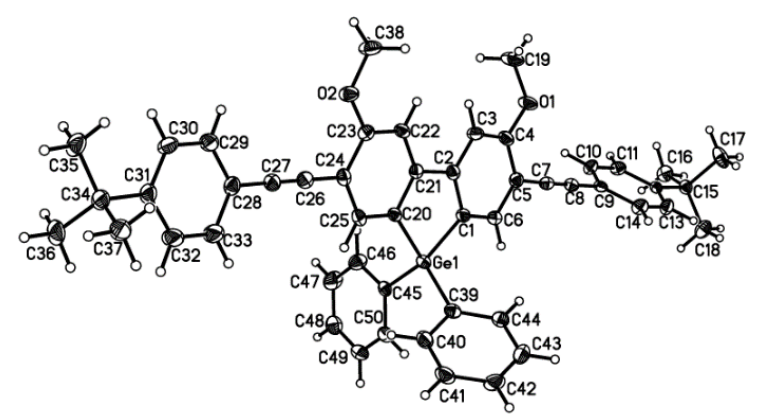

Figure 1. Molecular structure of 4c. Hydrogen atoms and solvent molecules have been removed for clarity. Thermal ellipsoids are drawn at the $50 \%$ probability level. Selected bond distances $(\AA)$, bond angles (deg), and torsion angles (deg) for 4c: Ge1-C1 = 1.935(2), Ge1-C20 = 1.937(2), Ge1-C39= 1.930(2), Ge1-C45 = 1.932(2), C1-C2 = 1.407(3), C2-C21 = 1.490(3), C20-C21 = 1.407(3), C39-Ge1$\mathrm{C} 45=108.91(9), \mathrm{C} 1-\mathrm{Ge} 1-\mathrm{C} 20=89.16(8), \mathrm{C} 6-\mathrm{C} 5-\mathrm{C} 9-\mathrm{C} 14=112.72, \mathrm{C} 25-\mathrm{C} 24-\mathrm{C} 28-\mathrm{C} 33=9.87$.

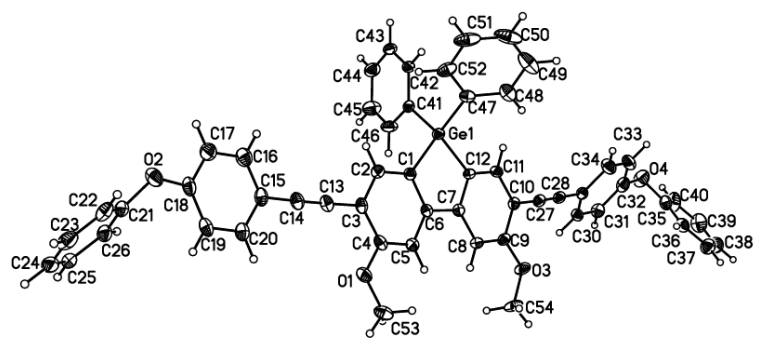

Figure 2. Molecular structure of 4d. Hydrogen atoms and solvent molecules have been removed for clarity. Thermal ellipsoids are drawn at the $50 \%$ probability level. Selected bond distances $(\AA)$, bond angles (deg), and torsion angles (deg) for 4d: Ge1-C1 = 1.944(3), Ge1-C12 = 1.934(3), Ge1-C41 = 1.937(3), Ge1-C47 = 1.942(3), C1-C6 = 1.404(4), C6-C7 = 1.484 (4), C7-C12 = 1.410(4), C13-C14 = 1.196(4), C27-C28 = 1.199(4), C1-Ge1-C12 = 88.94(11), C41-Ge1-C47 = 108.76(12), C6-C1-Ge1 = 109.39(19), C1-C6-C7 = 116.0(2), C12-C7-C6 = 115.9(2), C7-C12-Ge1 = 109.5(2). C2-C3-C15-C16 = 179.54, C11-C10-C29-C34 = 46.3.

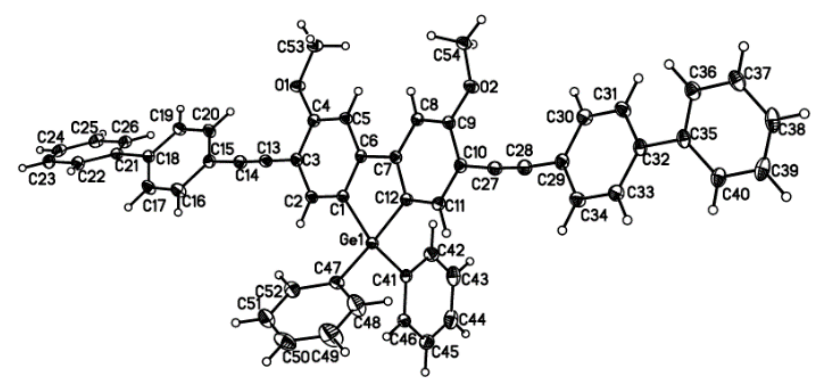

Figure 3. Molecular structure of 4e. Hydrogen atoms and solvent molecules have been removed for clarity. Thermal ellipsoids are drawn at the $50 \%$ probability level. Selected bond distances $(\AA)$, bond angles (deg), and torsion angles (deg) for 4e: Ge1-C1 = 1.9376(13), Ge1-C12 = 1.9399(13), Ge1-C47 = 1.9255(14), Ge1-C41 = 1.9385(14), C1-C6 = 1.4022(19), C6-C7 = 1.4838(18), C7-C12 = 1.4045(18), C13-C14 = 1.2017(19), C27-C28 = 1.1979(19), C47-Ge1-C41 = 114.70(6), C1-Ge1-C12 = 89.20(6). C2- 
$\mathrm{C} 3-\mathrm{C} 15-\mathrm{C} 16=32.43, \mathrm{C} 17-\mathrm{C} 18-\mathrm{C} 21-\mathrm{C} 22=37.52, \mathrm{C} 11-\mathrm{C}-10-\mathrm{C} 29-\mathrm{C} 34=169.42, \mathrm{C} 33-\mathrm{C} 32-\mathrm{C} 35-\mathrm{C} 40=$ 32.86 .

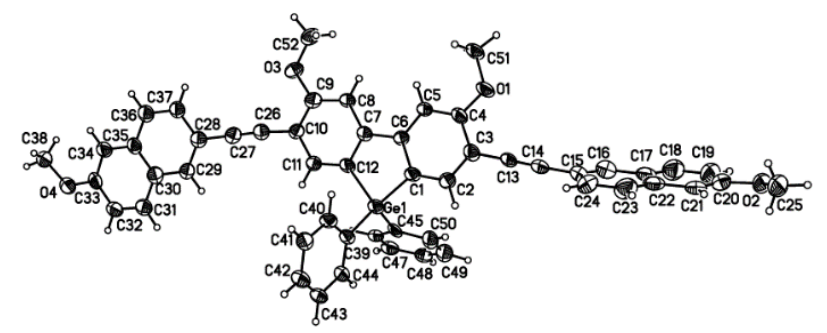

Figure 4. Molecular structure of $\mathbf{4 f}$. Hydrogen atoms and solvent molecules have been removed for clarity. Thermal ellipsoids are drawn at the $50 \%$ probability level. Selected bond distances $(\AA)$, bond angles (deg), and torsion angles (deg) for 4f: Ge1-C1 = 1.939(8), Ge1-C12 = 1.919(9), Ge1-C39= 1.959(9), Ge1-C45 = 1.908(9), C6-C7 = 1.497(11), C1-C6 = 1.412(11), C6-C7 = 1.497(11), C7-C12 = 1.398(11), C45-Ge1-C39 = 116.3(4), C1-Ge1-C12 = 89.1(4). C2-C3-C15-C16 = 61.87, C11-C10-C28$\mathrm{C} 37=172.26$.

2.3. Electronic Transitions

The UV-vis absorption and emission spectra of $\mathbf{4 a - 4 f}$ are shown in Figures 5a and 5b, respectively. The germafluorenes exhibited absorbance and emission energies that ranged from $371-388 \mathrm{~nm}$ (for the lowest energy absorbance bands) and emission bands (the highest energy bands) from 401-418 $\mathrm{nm}$ and they follow the order: $\mathbf{4 a}>\mathbf{4} \mathbf{c} \sim \mathbf{4 b}>\mathbf{4 d}>\mathbf{4 e}>\mathbf{4 f}$. The photophysical properties of $\mathbf{4 a - 4 f}$ are summarized in Table 2. Compounds 4a-4f exhibit similar absorption and emission maxima to the data obtained for the corresponding silafluorenes and for other related silafluorenes.[42-45] The intense absorption bands observed for the germafluorenes $\mathbf{4 a - 4 f}$ between $371-388 \mathrm{~nm}$ are attributed to the $\pi-\pi^{*}$ transitions that arise from the initial and excited states, $\mathrm{HOMO} / \mathrm{HOMO}_{-1}$ and $\mathrm{LUMO} \mathrm{LUMO}{ }_{+1}$, respectively. These molecular orbitals are appreciably delocalized over the germafluorene network based on theoretical studies focused on silafluorene analogs. [48, 49] The emission spectra for $\mathbf{4 a - 4 f}$ show two major bands with the higher energy emission band having the stronger intensity. Compounds $\mathbf{4 a - 4 f}$ exhibit moderate to strong blue emission in solution with quantum yields between $0.64-0.83$ in the order of $\mathbf{4 b}>\mathbf{4 c}>\mathbf{4 f}>\mathbf{4 d}>\mathbf{4 a}>\mathbf{4 e}$. The quantum yields for germafluorenes described herein are, in general, lower than the corresponding silafluorenes (range 0.80-0.89).[44] The reason for the decrease in the quantum efficiency for the germafluorenes vs. silafluorenes is not known. Lower quantum yields have been reported for several germafluorenes relative to their related silafluorene derivatives.[29] In contrast, Tilley and coworkers have reported high quantum efficiency values of 0.80 to 1.0 for related pairs of 
fluorinated sila- and germafluorene systems. [34, 35] Mullin and coworkers reported the photoluminescence of a series of Group 14 metalloles containing Si, Ge, and Sn.[50] The germoles exhibited the highest PL quantum yields in solution whereas the stannoles were the weakest emitters due to the heavy-atom effect of tin. Tamao and co-workers reported a theoretical study on related Group 14 metalloles containing $\mathrm{Si}, \mathrm{Ge}$, and $\mathrm{Sn}$ with thienyl groups bound to the 2,5-positions of the ring.[51] Their study indicated that the $\sigma^{*}-\pi^{*}$ conjugation becomes less effective and the bond distances elongated going from the silole to the heavier stannole. The silole and germole had similar quantum yields whereas the stannole had a much lower quantum yield, probably due to the heavy element effect of the tin atom. [51]
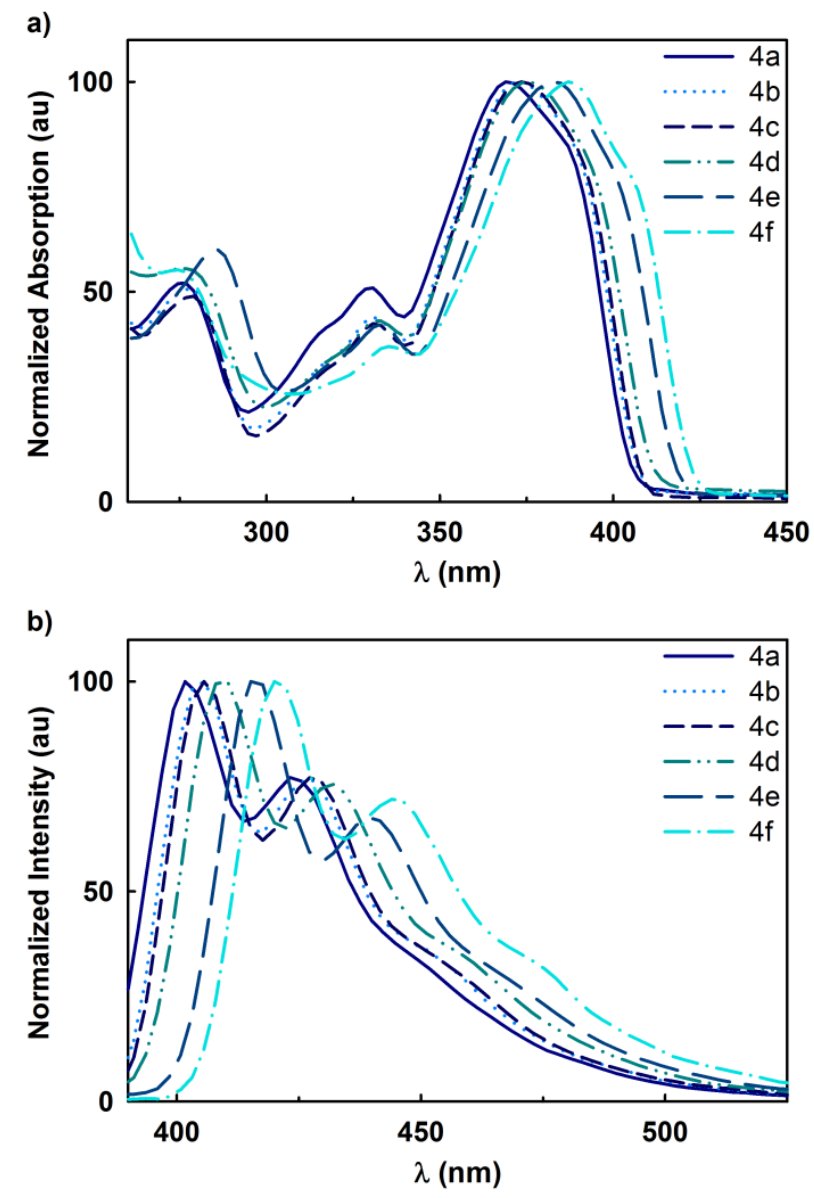

Figure 5. (a) Normalized UV/Vis and (b) fluorescence spectra of $\mathbf{4 a - 4 f}$ in $\mathrm{CH}_{2} \mathrm{Cl}_{2}$.

Table 2. UV-Visible and Fluorescence Spectral Data for Germafluorenes 4a-4f.

\begin{tabular}{|l|l|l|l|l|l|}
\hline Comp & $\lambda_{\max }{ }^{a}$ & $\log$ & $\lambda_{\max }{ }^{b}$ & $\Phi_{\mathrm{f}}{ }^{c}$ & $\mathrm{~T}_{m}{ }^{d} / \mathrm{T}_{d}{ }^{e}$ \\
\hline
\end{tabular}




\begin{tabular}{|l|l|l|l|l|l|}
\hline pound & $\begin{array}{l}\text { absorbance } \\
(\mathrm{nm})\end{array}$ & $\varepsilon$ & $\begin{array}{l}\text { fluorescen } \\
\mathrm{ce} \\
(\mathrm{nm})\end{array}$ & & $\left({ }^{\circ} \mathrm{C}\right)$ \\
\hline 4a & $278,331,371$ & 4.25 & 401,424 & 0.65 & $301 / 345$ \\
\hline 4b & $274,332,375$ & 4.54 & 404,427 & 0.83 & $255 / 395$ \\
\hline 4c & $274,332,374$ & 4.59 & 404,428 & 0.77 & $350 / 401$ \\
\hline 4d & $274,333,377$ & 4.58 & 409,433 & 0.68 & $201 / 370$ \\
\hline 4e & $286,334,384$ & 4.55 & 417,440 & 0.64 & $297 / 401$ \\
\hline 4f & $278,336,388$ & 4.51 & 418,443 & 0.75 & $298 / 445$ \\
\hline
\end{tabular}

Measurements were performed in $\mathrm{CH}_{2} \mathrm{Cl}_{2}$ at room temperature.

${ }^{a} 1 \times 10^{-5} \mathrm{M} .{ }^{b} 1 \times 10^{-6} \mathrm{M}$. ${ }^{c}$ Excitation at $350 \mathrm{~nm}$ with anthracene as the standard. ${ }^{d}$ Melting points measured by DSC. ${ }^{e}$ Decomposition temperatures (5\% weight loss) measured by TGA. The $\Phi_{\mathrm{F}}$ is the average value of repeated measurements within $\pm 5 \%$ error.

As seen with compounds $\mathbf{4 a - 4 f}$ and other related fluorescent molecules, strong $\pi$-donor and $\pi$-acceptor substituents and extending conjugation can give rise to red-shifted absorption and emission maxima.[52] The absorption and emission maxima are nearly identical for $\mathbf{4 a - 4 c}$, but $\mathbf{4 a}$ contains an electronwithdrawing fluoro substituent bound to the aryl unit. As a result, 4a possesses the highest energy absorption and emission maxima for the series of germafluorenes described herein. These inductive effects are in agreement with previously predicted and observed trends. [52] Compounds $\mathbf{4 d - 4 f}$, display a larger extended conjugation and as a result they exhibit a lower energy emission maximum.

Germafluorenes 4a-4f were examined by differential scanning calorimetry (DSC) and thermogravimetric analysis (TGA), and the results are listed in Table 2. DSC analyses of $\mathbf{4 a - 4 f}$ showed fairly high melting points between $201-350{ }^{\circ} \mathrm{C}$ and no glass transition temperatures were found. The highest melting point was observed for compound 4c. The TGA results demonstrate that the new germafluorenes 4a-4f have good thermal stability. The stability order with respect to thermal decomposition of the germafluorenes is $\mathbf{4 f}>\mathbf{4 e}=\mathbf{4 c}>\mathbf{4 b}>\mathbf{4 d}>\mathbf{4 a}$. The decomposition temperatures $\left(T_{\mathrm{d}}\right)$ corresponding to a $5 \%$ weight loss were measured between $345-445{ }^{\circ} \mathrm{C}$ for $\mathbf{4 a}-\mathbf{4 f}$, respectively, which are significantly higher than a carbon-containing fluorene derivative containing an alkynyl(phenyl) substituent at the 2,7-positions of the fluorene ring $\left(\mathrm{T}_{\mathrm{d}}=302{ }^{\circ} \mathrm{C}\right) .[53]$ 
In conclusion, six new 2,7-bis(alkynyl(aryl))-3,6-dimethoxy-9,9-diphenylgermafluorenes 4a-4f containing different alkynyl(aryl) groups bound to the germafluorene ring were synthesized in good yields (50-80\%). The new compounds were characterized using a variety of techniques including UVVis, fluorescence and in several cases, X-ray crystallography. All of the new germafluorenes reported exhibit moderate to strong blue emission in solution with quantum yields ranging from $0.64-0.83$. The absorption and emission properties were similar to the related silafluorenes reported previously however the quantum efficiencies were lower, in general, for the germafluorene series reported herein. [44] The molecules exhibited good thermal stability and fluorescence was observed in the solid-state.

\section{Experimental section}

\subsection{General Procedures.}

The reactions to prepare compounds $\mathbf{3}$ and $\mathbf{4 a - 4 f}$ were performed under an argon atmosphere utilizing standard Schlenk techniques and flame-dried glassware. Tetrahydrofuran was dried and distilled under $\mathrm{N}_{2}$ using sodium and 9-fluorenone. Piperidine was distilled over $\mathrm{CaH}_{2}$ under reduced pressure and stored under an argon atmosphere. The solvents, chloroform, dichloromethane, methanol, ethanol, pentane, and hexane were used as received. $O$-dianisidine was purchased from Alfa Aesar. The compounds, 4,4'dibromo-3,3'-dimethoxy-1,1'-biphenyl (1) and 4,4'-dibromo-2,2'-diiodo-5,5'-dimethoxy-1,1'-biphenyl (2) were prepared following published procedures. [42] The following compounds were purchased from Sigma Aldrich and used as received: 1-ethynyl-3-fluorobenzene, 1-ethynyl-4-phenoxybenzene, 2-ethynyl6-methoxynaphthalene, 4-ethynylbiphenyl, 4-ethynyltoluene, 4-tert-butylphenylacetylene, dichlorodiphenylgermane, $n$-butyllithium (1.6 M in hexanes), tetrakis(triphenylphosphine)palladium(0) (stored in an inert atmosphere drybox), copper(I) iodide, and piperdine. Chloroform- $d$ was purchased from Cambridge Isotopes, Inc. NMR spectra were collected on an Agilent DD2 $600\left({ }^{1} \mathrm{H}\right.$ recorded at 600 $\mathrm{MHz},{ }^{13} \mathrm{C}$ at $151 \mathrm{MHz}$, and ${ }^{19} \mathrm{~F}$ at $564 \mathrm{MHz}$ ) or on a Bruker Advance-300 MHz $\left({ }^{1} \mathrm{H}\right.$ recorded at $300 \mathrm{MHz}$,

${ }^{13} \mathrm{C}$ at $75 \mathrm{MHz}$ ) at ambient temperature. Elemental analyses were performed by Robertson Microlit Labs, 
Inc., Ledgewood, NJ. A JEOL M Station-JMS 70 mass spectrometer was used to obtain high resolution mass spectra (EI). Melting point determinations were obtained on a Mel-Temp melting point apparatus and are uncorrected. UV-vis and fluorescence spectra were collected on a Cary 50 Bio UV-visible and Cary Eclipse Fluorescence spectrophotometer, respectively.

3.2. Preparation of 2,7-Dibromo-3,6-dimethoxy-9,9-diphenylgermafluorene (3).

A sample of 4,4'-dibromo-2,2'-diiodo-5,5'-dimethoxy-1,1'-biphenyl (2) [42] (5.0 g, $8.01 \mathrm{mmol})$ was dissolved in THF $(160 \mathrm{~mL})$ in a flame-dried four-necked flask equipped with a pressure-equilibration addition funnel, thermometer, and magnetic stirrer under an argon atmosphere. The clear solution was chilled to $-95{ }^{\circ} \mathrm{C}$ in a methanol/ $\mathrm{N}_{2}$ bath. The addition of water to the bath provides a slush (ratio of $\left.\mathrm{H}_{2} \mathrm{O}: \mathrm{MeOH}, 1: 4\right)$ that helps to prevent the possibility of the bath freezing and breaking the flask. Next, $n$ BuLi (10.27 mL, 1.6 M in hexanes) was added dropwise over $2.5 \mathrm{~min}$ to the rapidly stirring solution. It is important not to allow the reaction mixture temperature to exceed $-90{ }^{\circ} \mathrm{C}$, otherwise the lithium-iodine exchange selectivity can be lost as reaction at the bromine sites can occur. The solution changed from clear to yellow after the first drop of $n$-BuLi was added, and when half of the total amount of $n$-BuLi was added a bright yellow slurry formed. As additional $n$-BuLi was added to the reaction flask the slurry dissolved. Immediately after the addition of $n$-BuLi was complete, neat dichlorodiphenylgermane (2.18 $\mathrm{mL}, 8.82 \mathrm{mmol}$ ) was injected into the flask in one portion by a syringe. The resulting light yellow reaction mixture was then immediately removed from the bath and stirred at room temperature overnight under argon. A saturated ammonium chloride solution was then added to the reaction mixture, the organic layer extracted with chloroform and washed with brine. The resulting organic layer was then dried with magnesium sulfate. After filtering, the solvent was removed by rotary evaporation. The germafluorene product (3) was purified by silica gel column chromatography (dichloromethane/hexane 1/1) followed by recrystallization from dichloromethane/ethanol. The white crystalline solid $\mathbf{3}$ (3.21 g, 67\%) was analyzed by NMR and confirmed by comparison to literature values for the related silafluorene. [41, 43] Mp: 268$270{ }^{\circ} \mathrm{C} . \quad{ }^{1} \mathrm{H}$ NMR $\left(600 \mathrm{MHz}, \mathrm{CDCl}_{3}\right): \delta 7.84(\mathrm{~s}, 2 \mathrm{H}), 7.56-7.53(\mathrm{~m}, 4 \mathrm{H}), 7.44-7.36(\mathrm{~m}, 8 \mathrm{H}), 4.06(\mathrm{~s}$, 
$6 \mathrm{H}) .{ }^{13} \mathrm{C}\left\{{ }^{1} \mathrm{H}\right\} \mathrm{NMR}\left(151 \mathrm{MHz}, \mathrm{CDCl}_{3}\right) \delta 157.8,147.4,137.9,134.7,134.1,131.5,130.0,128.8,112.9$, 105.8, 56.5. UV-Vis $\left(\mathrm{CH}_{2} \mathrm{Cl}_{2}, 1.0 \times 10^{-5} \mathrm{M}\right): \lambda_{\max } 334 \mathrm{~nm}(\log \varepsilon=4.28), 381 \mathrm{~nm}$ (br). Fluorescence $\left(\mathrm{CH}_{2} \mathrm{Cl}_{2}, 1.0 \times 10^{-6} \mathrm{M}, \lambda_{\text {ex }} 315 \mathrm{~nm}\right): \lambda_{\text {em }}(\mathrm{nm}) 394,424,449$. Anal. Calcd for $\mathrm{C}_{26} \mathrm{H}_{20} \mathrm{Br}_{2} \mathrm{O}_{2} \mathrm{Ge}: \mathrm{C}, 52.32 ; \mathrm{H}$, 3.38. Found: C, 52.45; H, 3.37.

3.3. General procedure for the preparation of 2,7-alkynyl(aryl)-3,6-dimethoxy-9,9diphenylgermafluorenes.

A sample of 2,7-dibromo-3,6-dimethoxy-9,9-diphenylgermafluorene $\left.3(0.250 \mathrm{~g}, 0.419 \mathrm{mmol}), \mathrm{Pd}_{(} \mathrm{PPh}_{3}\right)_{4}$ $(0.048 \mathrm{~g}, 0.042 \mathrm{mmol})$, and $\mathrm{CuI}(0.016 \mathrm{~g}, 0.085 \mathrm{mmol})$ were added to a three-necked $15 \mathrm{~mL}$ round-bottom flask equipped with a reflux condenser and magnetic stir bar. Then, piperidine $(4.81 \mathrm{~mL}, 48.6 \mathrm{mmol})$ and the corresponding alkynyl(aryl) $(1.24 \mathrm{mmol})$ were added to the flask. The reaction mixture was stirred at $80{ }^{\circ} \mathrm{C}$ overnight (approximately $12 \mathrm{~h}$ ). The solvent was removed by rotary evaporation then the reaction mixture separated by silica gel chromatography using dichloromethane/hexane as the eluent. Recrystallization from dichloromethane/pentane gave pure products $\mathbf{4 a - 4 f}$. Characterization of the new germafluorenes $\mathbf{4 a - 4 f}$ is described in subsequent paragraphs.

\subsection{Preparation of germafluorene (4a).}

Compound 4a was prepared following the general procedure described in section 3.3 with 1-ethynyl-3fluorobenzene used as the alkyny(aryl) for the coupling reaction. Compound $\mathbf{4 a}$ was isolated as a bright yellow powder $(0.202 \mathrm{~g}, 71 \%$ yield $) . \mathrm{Mp}: 234-235^{\circ} \mathrm{C}$. X-ray-quality crystals were obtained by slow evaporation of a dichloromethane solution of $\mathbf{4 a}$ at room temperature. ${ }^{1} \mathrm{H} \mathrm{NMR}\left(600 \mathrm{MHz}, \mathrm{CDCl}_{3}\right): \delta$ $7.85(\mathrm{~s}, 2 \mathrm{H}), 7.59(\mathrm{~m}, 4 \mathrm{H}), 7.43-7.36(\mathrm{~m}, 8 \mathrm{H}), 7.34-7.23(\mathrm{~m}, 5 \mathrm{H}), 7.0-7.05(\mathrm{~m}, 2 \mathrm{H}), 4.09(\mathrm{~s}, 6 \mathrm{H})$. 
${ }^{13} \mathrm{C}\left\{{ }^{1} \mathrm{H}\right\} \mathrm{NMR}\left(151 \mathrm{MHz}, \mathrm{CDCl}_{3}\right): \delta 162.5(\mathrm{~d}, J=246 \mathrm{~Hz}), 162.3,148.7,138.6,134.8,134.6,130.4$, $130.0(\mathrm{~d}, J=9 \mathrm{~Hz}), 129.9,128.8,127.6(\mathrm{~d}, J=1 \mathrm{~Hz}), 125.5(\mathrm{~d}, \mathrm{~J}=9 \mathrm{~Hz}), 118.5(\mathrm{~d}, J=23 \mathrm{~Hz}), 115.6(\mathrm{~d}$, $J=21 \mathrm{~Hz}), 112.7,104.7,93.7(\mathrm{~d}, \mathrm{~J}=3 \mathrm{~Hz}), 87.2,56.2 .{ }^{19} \mathrm{~F}$ NMR $\left(564 \mathrm{MHz}, \mathrm{CDCl}_{3}\right): \delta-113.2(\mathrm{~m})$. HRMS (EI): calcd. for $\mathrm{C}_{42} \mathrm{H}_{28} \mathrm{~F}_{2} \mathrm{O}_{2} \mathrm{Ge}$ : 675.307, found 676.126. Anal. Calcd for $\mathrm{C}_{42} \mathrm{H}_{28} \mathrm{~F}_{2} \mathrm{O}_{2} \mathrm{Ge}$ : C, 74.70; H, 4.18. Found: C, 74.42; H, 4.30.

\subsection{Preparation of germafluorene (4b).}

Compound 4b was prepared following the general procedure described in Section 3.3 with 4ethynyltoluene as the alkynyl(aryl) for the coupling reaction. Compound $\mathbf{4 b}$ was isolated as a bright yellow powder $(0.221 \mathrm{~g}, 79 \%$ yield $)$. Mp: $265-266{ }^{\circ} \mathrm{C}$. X-ray-quality crystals were obtained by slow evaporation of a dichloromethane solution of the $\mathbf{4 b}$ at room temperature. ${ }^{1} \mathrm{H}$ NMR $\left(600 \mathrm{MHz}, \mathrm{CDCl}_{3}\right): \delta$ $7.85(\mathrm{~s}, 2 \mathrm{H}), 7.62-7.58(\mathrm{~m}, 4 \mathrm{H}), 7.48-7.44(\mathrm{~m}, 4 \mathrm{H}), 7.43-7.36(\mathrm{~m}, 8 \mathrm{H}), 7.17-7.13(\mathrm{~m}, 4 \mathrm{H}), 4.09$ (s, $6 \mathrm{H}), 2.37(\mathrm{~s}, 6 \mathrm{H}) .{ }^{13} \mathrm{C}\left\{{ }^{1} \mathrm{H}\right\} \mathrm{NMR}\left(151 \mathrm{MHz}, \mathrm{CDCl}_{3}\right): \delta 162.1,148.3,138.5,138.4,134.8,131.7,130.3$, 129.8, 129.2, 128.7, 120.5, 113.3, 104.7, 95.2, 85.6, 56.2, 21.7. HRMS (EI): calcd. for $\mathrm{C}_{44} \mathrm{H}_{34} \mathrm{O}_{2} \mathrm{Ge}$ : 667.38; Found, 668.177. Anal. Calcd for $\mathrm{C}_{44} \mathrm{H}_{34} \mathrm{O}_{2} \mathrm{Ge}: \mathrm{C}, 79.19 ; \mathrm{H}, 5.14$. Found: C, 78.86; H, 5.23.

3.6. Preparation of germafluorene $(\mathbf{4 c})$.

Compound $\mathbf{4 c}$ was prepared following the general procedure described in Section 3.3 with 4-tertbutylphenylacetylene as the alkynyl(aryl) for the coupling reaction. Compound $\mathbf{3 c}$ was isolated as a bright yellow powder $\left(0.156 \mathrm{~g}, 50 \%\right.$ yield). Mp: $324-325^{\circ} \mathrm{C}$. X-ray-quality crystals were obtained by slow evaporation of a dichloromethane solution $4 \mathbf{c}$ at room temperature. ${ }^{1} \mathrm{H}$ NMR $\left(600 \mathrm{MHz}, \mathrm{CDCl}_{3}\right)$ : $\delta$ $7.85(\mathrm{~s}, 2 \mathrm{H}), 7.61-7.58(\mathrm{~m}, 4 \mathrm{H}), 7.50-7.47(\mathrm{~m}, 4 \mathrm{H}), 7.42-7.33(\mathrm{~m}, 12 \mathrm{H}), 4.08(\mathrm{~s}, 6 \mathrm{H}), 1.32(\mathrm{~s}, 18 \mathrm{H})$.

${ }^{13} \mathrm{C}\left\{{ }^{1} \mathrm{H}\right\}$ NMR $\left(151 \mathrm{MHz}, \mathrm{CDCl}_{3}\right): \delta 162.2,151.5,148.3,138.5,134.8,131.4,130.3,129.8,128.7,125.4$, 120.6, 113.4, 104.8, 95.2, 85.6, 56.3, 34.9, 31.6. HRMS (EI): calcd. for $\mathrm{C}_{50} \mathrm{H}_{46} \mathrm{O}_{2} \mathrm{Ge}$ : 751.539; Found, 752.2709. Anal. Calcd for $\mathrm{C}_{50} \mathrm{H}_{46} \mathrm{O}_{2} \mathrm{Ge}: \mathrm{C}, 79.91 ; \mathrm{H}, 6.17$. Found: $\mathrm{C}, 79.75 ; \mathrm{H}, 6.04$. 


\subsection{Preparation of germafluorene (4d).}

Compound 4d was prepared following the general procedure described in section 3.3 with 1-ethynyl-4phenoxybenzene as the alkynyl(aryl) for the coupling reaction. Compound $\mathbf{4 d}$ was isolated as bright yellow crystals $\left(0.276 \mathrm{~g}, 80 \%\right.$ yield). Mp: $218-219{ }^{\circ} \mathrm{C}$. X-ray-quality crystals were obtained by slow evaporation of a dichloromethane solution of $\mathbf{4 d}$ at room temperature. ${ }^{1} \mathrm{H} \mathrm{NMR}\left(600 \mathrm{MHz}, \mathrm{CDCl}_{3}\right): \delta$ $7.85(\mathrm{~s}, 2 \mathrm{H}), 7.59$ (d, $J=7.2 \mathrm{~Hz}, 4 \mathrm{H}), 7.52(\mathrm{~d}, J=8.7 \mathrm{~Hz}, 4 \mathrm{H}), 7.41(\mathrm{~s}, 2 \mathrm{H}), 7.42-7.34(\mathrm{~m}, 10 \mathrm{H}), 7.14(\mathrm{t}$, $J=7.2 \mathrm{~Hz}, 2 \mathrm{H}), 7.04(\mathrm{~d}, \mathrm{~J}=7.8 \mathrm{~Hz}, 4 \mathrm{H}), 6.96(\mathrm{~d}, J=8.5 \mathrm{~Hz}, 4 \mathrm{H}), 4.08(\mathrm{~s}, 6 \mathrm{H}) .{ }^{13} \mathrm{C}\left\{{ }^{1} \mathrm{H}\right\} \mathrm{NMR}(151$ $\left.\mathrm{MHz}, \mathrm{CDCl}_{3}\right): \delta 162.1,157.6,156.6,148.4,138.4,134.8,134.7,133.4,130.3,130.0,129.8,128.8,123.9$, 119.6, 118.5, 118.4, 113.3, 104.7, 94.6, 85.7, 56.2. HRMS (EI): calcd. for $\mathrm{C}_{54} \mathrm{H}_{38} \mathrm{O}_{4} \mathrm{Ge}$ : 823.517. Found, 824.198. Anal. Calcd for $\mathrm{C}_{54} \mathrm{H}_{38} \mathrm{O}_{4} \mathrm{Ge}: \mathrm{C}, 78.76 ; \mathrm{H}, 4$.65. Found: C, 78.57; H, 4.58.

\subsection{Preparation of germafluorene (4e).}

Compound 4e was prepared following the general procedure described in section 3.3 with 4ethynylbiphenyl was used as the alkynyl(aryl) for the coupling reaction. Compound $\mathbf{4 e}$ was isolated as a bright yellow powder $\left(0.207 \mathrm{~g}, 62 \%\right.$ yield). Mp: $328-329^{\circ} \mathrm{C}$. X-ray-quality crystals were obtained by slow evaporation of a dichloromethane solution of the product at room temperature. ${ }^{1} \mathrm{H} \mathrm{NMR}(600 \mathrm{MHz}$, $\left.\mathrm{CDCl}_{3}\right): \delta 7.88(\mathrm{~s}, 2 \mathrm{H}), 7.64-7.57(\mathrm{~m}, 16 \mathrm{H}), 7.47-7.34(\mathrm{~m}, 14 \mathrm{H}), 4.11(\mathrm{~s}, 6 \mathrm{H}) .{ }^{13} \mathrm{C}\left\{{ }^{1} \mathrm{H}\right\} \mathrm{NMR}(151$ $\left.\mathrm{MHz}, \mathrm{CDCl}_{3}\right): \delta 162.2,148.6,140.9,140.5,138.6,134.8,134.7,132.3,130.4,129.9,129.0,128.7,127.7$, 127.2, 127.1, 122.5, 113.2, 104.7, 94.9, 87.0, 56.3. Anal. Calcd for $\mathrm{C}_{54} \mathrm{H}_{38} \mathrm{O}_{2} \mathrm{Ge}: \mathrm{C}, 81.94 ; \mathrm{H}$, 4.84. Found: C, 81.54; H, 4.81 .

3.9. Preparation of 2,7-(2-ethynyl-6-methoxynaphthalene)-3,6-dimethoxy-9,9-diphenylgermafluorene (4).

Compound $\mathbf{4 f}$ was prepared following the general procedure described in section 3.3 with 2-ethynyl-6methoxynaphthalene as the alkynyl(aryl) for the coupling reaction. Compound $\mathbf{4 f}$ was isolated as a bright yellow powder ( $0.202 \mathrm{~g}, 60 \%$ yield). Mp: $295-296^{\circ} \mathrm{C}$. X-ray-quality crystals were obtained by slow 
evaporation of a dichloromethane solution of the product at room temperature. ${ }^{1} \mathrm{H}$ NMR $(600 \mathrm{MHz}$, $\left.\mathrm{CDCl}_{3}\right): \delta 8.01(\mathrm{~s}, 2 \mathrm{H}), 7.90(\mathrm{~s}, 2 \mathrm{H}), 7.72-7.67(\mathrm{~m}, 4 \mathrm{H}), 7.63-7.56(\mathrm{~m}, 6 \mathrm{H}), 7.43(\mathrm{~s}, 2 \mathrm{H}), 7.41-7.36$ $(\mathrm{m}, 5 \mathrm{H}), 7.16-7.13(\mathrm{~m}, 2 \mathrm{H}), 7.12-7.10(\mathrm{~m}, 2 \mathrm{H}), 4.12(\mathrm{~s}, 6 \mathrm{H}), 3.93(\mathrm{~s}, 6 \mathrm{H}) .{ }^{13} \mathrm{C}\left\{{ }^{1} \mathrm{H}\right\} \mathrm{NMR}(151 \mathrm{MHz}$ $\left.\mathrm{CDCl}_{3}\right): \delta 162.3,158.4,148.4,138.6,134.8,134.8,134.2,131.4,130.4,129.8,129.5,129.3,128.7$, 128.67, 126.8, 119.5, 118.6, 113.4, 106.0, 104.8, 95.6, 86.1, 56.3, 55.5. Anal. Calcd for $\mathrm{C}_{52} \mathrm{H}_{38} \mathrm{O}_{4} \mathrm{Ge}$ : C, 78.12; H, 4.79. Found: C, 77.88; H, 4.79.

\subsection{X-ray Structure Determination of $\mathbf{4 c - 4 f}$.}

Crystals of X-ray diffraction quality were grown by slow evaporation of dichloromethane solutions of $\mathbf{4 c -}$ 4f. Crystals were mounted on MiTeGen cryoloops in random orientations for data collection. Preliminary examination and data collection were performed using a Bruker X8 Kappa Apex II Charge Coupled Device (CCD) Detector system single crystal X-Ray diffractometer equipped with an Oxford Cryostream LT device. All data were collected using graphite monochromated Mo K $\alpha$ radiation $(\lambda=0.71073 \AA)$ from a fine focus sealed tube X-Ray source. Preliminary unit cell constants were determined with a set of 36 narrow frame scans. Typical data sets consist of combinations of $\varpi$ and $\phi$ scan frames with typical scan width of $0.5^{\circ}$ and counting time of 10-30 seconds/frame at a crystal to detector distance of $4.0 \mathrm{~cm}$. The collected frames were integrated using an orientation matrix determined from the narrow frame scans. Apex II and SAINT software packages were used for data collection and data integration. [54] Analysis of the integrated data did not show any decay. Final cell constants were determined by global refinement of reflections harvested from the complete data sets. A summary of crystal structure parameters are listed in Table 1. Structure solution and refinement were carried out using the SHELXTL- PLUS software package. [55] The structures were solved by direct methods and refined successfully in the space groups, $\mathrm{P} \overline{1}$, for compounds $\mathbf{4 c}, \mathbf{4 d}$, and $\mathbf{4 e}$ and in the monoclinic space group $\mathrm{P} 2_{1} / \mathrm{c}$ for $\mathbf{4 f}$. Full matrix leastsquares refinements were carried out by minimizing $\Sigma \mathrm{w}\left(\mathrm{F}_{\mathrm{o}}{ }^{2}-\mathrm{F}_{\mathrm{c}}{ }^{2}\right)^{2}$. The non-hydrogen atoms were 
refined anisotropically to convergence. All hydrogen atoms were treated using appropriate riding model (AFIX m3). One of the phenyl groups (2-C atoms) in $\mathbf{4 c}$ is disordered and the disorder was modeled with 2 sets of partial occupancy Cs (51:49\%). Compound $\mathbf{4 d}$ crystallized with a $0.5 \mathrm{CH}_{2} \mathrm{Cl}_{2}$ molecule per unit cell. Diffraction data for $\mathbf{4 f}$ are extremely weak resulting in low ratio of observed /unique reflections (35\%) and high $\mathrm{R}_{\mathrm{int}}(28 \%)$. Complete listings of positional and isotropic displacement coefficients for hydrogen atoms, anisotropic displacement coefficients for the non-hydrogen atoms are listed in Supplementary Material. A table of calculated and observed structure factors is available in electronic format.

\section{Acknowledgement}

Funding from the National Science Foundation (CHE-1362431) for support of this work, for an Agilent DD2 600 MHz NMR spectrometer (MRI-0959360), and for an Apex-II diffractometer (MRI, CHE0420497) is acknowledged and greatly appreciated.

\section{References}

[1] G. Zhang, F. Hu, D. Zhang, Langmuir 31 (2015) 4593-4604.

[2] W. Ni, X. Wan, M. Li, Y. Wang, Y. Chen, Chem. Commun. 51 (2015), 4936-4950.

[3] Q.-W. Zhang, K. An, W. He, Synlett 26 (2015) 1145-1152.

[4] M. Shimizu, Chem. Rec. 15 (2015) 73-85. 
[5] A. Sharma, D. Pathak, T. Wagner, J. Optoelectronics Adv. Materials 16 (2014) 1257-1268.

[6] J. L. Mullin, H. J. Tracy, A. Qin, B. Z. Tang (Eds.), Aggregation-Induced Emission: Fundamentals and Applications, vols. 1 and 2; John Wiley and Sons Ltd, 2013, pp. 39-60.

[7] J. Y. Corey, A. Qin, B. Z. Tang (Eds.), Aggregation-Induced Emission: Fundamentals and Applications, vols. 1 and 2; John Wiley and Sons Ltd, 2013, pp. 1-37.

[8] C.-W. Lin, S.-T. Chen, A. Qin, B. Z. Tang (Eds.), Aggregation-Induced Emission: Applications, John Wiley and Sons Ltd, 2013, pp. 1-41.

[9] A. Qin, J. W. Y. Lam B. Z. Tang, Progress in Polymer Science 37 (2012) 182-209.

[10] J. Y. Corey, Adv. Organomet. Chem. 59 (2011) 1-180.

[11] J. Y. Corey, Adv. Organomet. Chem. 59 (2011) 181-328.

[12] S. A. Ponomarenko, S. Kirchmeyer, Adv. Polym. Sci. 235 (2011) 33-110

[13] M. Wang, G. Zhang, D. Zhang, D. Zhu, B. Z. Tang, J. Mater. Chem. 20 (2010) 1858-1867.

[14] S. Beaupré, P-L T. Boudreault, M. Leclerc Adv. Mater. 22 (2010) E6-E27.

[15] J. Chen, Y. Cao, Acct. Chem. Res. 42 (2009) 1709-1718.

[16] J. Ohshita, Macromol. Chem. Phys. 210 (2009) 1360-1370.

[17] W. W. H. Wong, J. F. Hooper, A. B. Holmes, Aust. J. Chem. 62 (2009) 393-401.

[18] A. R. Moustafa, M. Mahmoud, B. L. Pagenkopf, C. R. Chimie 12 (2009) 359-365.

[19] J. C. Sanchez, W. C. Trogler, Macromol. Chem. Phys. 209 (2008) 1527-1540.

[20] J. Chun, Y. Cao, Macromolecular Rapid Commun. 28 (2007) 1714-1742.

[21] B. Wrackmeyer, Heteroatom Chem. 17 (2006) 188-208.

[22] S. Yamaguchi, C. Xu, T. Okamoto, Pure Appl. Chem. 78 (2006) 721-730.

[23] S. J. Toal, W. C. Trogler, J. Mater. Chem. 16 (2006), 2871-2883.

[24] S M. Parke, M. P. Boone, E. Rivard, Chem. Commun. 52 (2016) 9485-9505.

[25] M. Hissler, P. W. Dyer, R. Réau, Coord. Chem. Rev. 244 (2003) 1-44.

[26] S. Yamaguchi, K. Tamao, J. Chem. Soc., Dalton Trans. (1998) 3693-3702.

[27] T. Agou, M. D. Hossain, T. Kawashima, T. Chem. Eur. J. 16 (2010) 368-375.

[28] M. Shimizu, K. Mochida, M. Katoh, T. Hiyama, J. Phys. Chem. 114 (2010) 10004-10014. 
[29] Y. Yabusaki, N. Ohshima, H. Kondo, T. Kusamoto, Y. Yamanoi, H. Nishihara, Chem. Eur. J. 16 (2010) 5581-5585.

[30] X. Zhan, S. Barlow, S. R. Marder, Chem. Commun. (2009) 1948-1955.

[31] N. Allard, R. B. Naïch, D. Gendron, P.-L. T. Boudreault, C. Tessier, S. Alem, S.-C.Tse, Y. Tao, M. Leclerc, M. Macromolecules 43 (2010) 2328-2333.

[32] C. RunFeng, Z. Rui, Z. Chao, L. ShuJuan, F. QuLi, H. Wei, Sci China Ser B-Chem 52 (2009) 212218.

[33] K. Geramita, J. McBee, Y. Tao, R. A. Segelman, T. D. Tilley, Chem. Commun. (2008) 5107-5109.

[34] K. Geramita, J. McBee, T. D. Tilley, J. Org. Chem. 74 (2009) 820-829.

[35] K. Geramita, Y. Tao, R. A. Segelman, T. D. Tilley, J. Org. Chem. 75 (2010) 1871-1887.

[36] O. Shynkaruk, G. He, R. McDonald, M. J. Ferguson, E. Rivard, Chem. Eur. J. 22 (2016) 248-257.

[37] K. Murakama, Y. Ooyama, H. Higashimura, J. Ohshita, Organometallics 35 (2016) 20-26.

[38] B. Wu, N. Yoshikai, Angew. Chem. Int. Ed., 54 (2015) 8736-8739.

[39] R. Shintani, C. Takagi, T. Ito, M. Naito, K. Nozaki, Angew. Chem. Int. Ed. 54 (2015) 1616-1620.

[40] M. Murai, K. Matsumoto, R. Okada, K. Takai, Org. Lett. 16 (2014) 6492-6495.

[41] R.-F. Chen, Q.-L. Fan, C. Zheng, W. Huang, Org. Lett. 8 (2006) 203-205.

[42] J. J. McDowell, I. Schick, A. Price, D. Faulkner, G. Ozin, Macromolecules 46 (2013) 6794-6805.

[43] L. Li, C. Xu, S. Li, Tetrahedron Lett. 51 (2010) 622-624.

[44] D. H. Hammerstroem, J. Braddock-Wilking, N. P. Rath, J. Organomet. Chem. 813 (2016) 110-118.

[45] L. Li, S. Li, C.-H. Zhao, C. Xu, Eur. J. Inorg. Chem. (2014) 1880-1885.

[46] K. Ogawa, Y. Takeuchi, G. Manuel, Acta Cryst. C50 (1994) 1337-1339.

[47] D. S. Brown, A. G. Massey, T. K. Mistry, J. Organomet. Chem. 302 (1986) 343-350.

[48] R.-F.Chen, L.-Y. Liu, H. Fu, C. Zheng, H. Xu, Q.-L. Fan, W. Huang, J. Phys. Chem. B 115 (2011) 242-248.

[49] R.-F. Chen, C. Zheng, Q.-L Fan, W. Huang, J. Comput. Chem. 28 (2007) 2091-2101.

[50] H. J. Tracy, J. L. Mullin, W. T. Klooster J. A. Martin, J. Haug, S. Wallace, I. Rudloe, K. Watts, Inorg. Chem. 44 (2005), 2003-2011.

[51] S. Yamaguchi, Y. Itami, K. Tamao, Organometallics 17 (1998) 4910-4916.

[52] X. Zhan, S. Barlow, S. R. Marder, Chem. Commun. (2009) 1948-1955. 
[53] Z. Wang, H. Shao, J. Ye, L. Zhang, P. Lu, Adv. Funct. Mater.17 (2007) 253-263.

[54] Bruker Analytical X-Ray, Madison, WI, 2015.

[55] G. M. Sheldrick Acta Cryst. A64 (2008),112-122. 


\section{Luminescent 2,7-Disubstituted Germafluorenes}

Douglas W. Hammerstroem, Janet Braddock-Wilking*, and Nigam P. Rath

Department of Chemistry and Biochemistry and Center for Nanoscience, University of Missouri St Louis, St. Louis, Missouri 63121, United States

Graphical Abstract

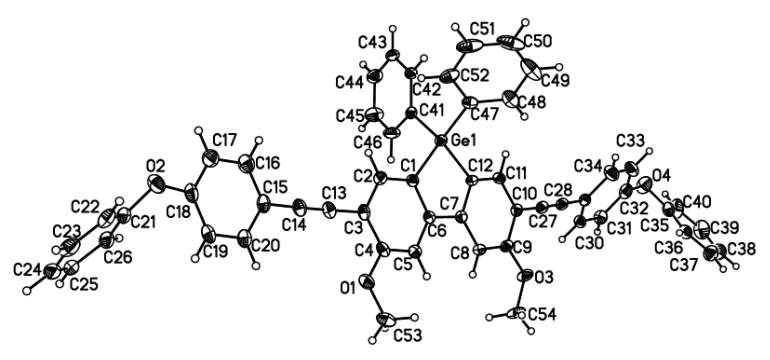

